\title{
Optical and microphysical characterization of aerosol layers over South Africa by means of multi-wavelength depolarization and Raman lidar measurements
}

\author{
Elina Giannakaki $^{1, \text { a }}$, Pieter G. van $\mathrm{Zyl}^{2}$, Detlef Müller ${ }^{3}$, Dimitris Balis ${ }^{4}$, and Mika Komppula ${ }^{1}$ \\ ${ }^{1}$ Finnish Meteorological Institute, P.O. Box 1627, 70211, Kuopio, Finland \\ ${ }^{2}$ Unit for Environmental Sciences and Management, North-West University, Potchefstroom, South Africa \\ ${ }^{3}$ School of Physics, Astronomy and Mathematics, University of Hertfordshire, Hatfield, UK \\ ${ }^{4}$ Laboratory of Atmospheric Physics, Thessaloniki, Greece \\ ${ }^{\mathrm{a}}$ on leave from: Department of Environmental Physics and Meteorology, Faculty of Physics, \\ University of Athens, Athens, Greece
}

Correspondence to: E. Giannakaki (eleni.giannakaki@fmi.fi)

Received: 16 November 2015 - Published in Atmos. Chem. Phys. Discuss.: 15 December 2015

Revised: 31 May 2016 - Accepted: 6 June 2016 - Published: 5 July 2016

\begin{abstract}
Optical and microphysical properties of different aerosol types over South Africa measured with a multiwavelength polarization Raman lidar are presented. This study could assist in bridging existing gaps relating to aerosol properties over South Africa, since limited long-term data of this type are available for this region. The observations were performed under the framework of the EUCAARI campaign in Elandsfontein. The multi-wavelength Polly ${ }^{X T}$ Raman lidar system was used to determine vertical profiles of the aerosol optical properties, i.e. extinction and backscatter coefficients, Ångström exponents, lidar ratio and depolarization ratio. The mean microphysical aerosol properties, i.e. effective radius and single-scattering albedo, were retrieved with an advanced inversion algorithm. Clear differences were observed for the intensive optical properties of atmospheric layers of biomass burning and urban/industrial aerosols. Our results reveal a wide range of optical and microphysical parameters for biomass burning aerosols. This indicates probable mixing of biomass burning aerosols with desert dust particles, as well as the possible continuous influence of urban/industrial aerosol load in the region. The lidar ratio at $355 \mathrm{~nm}$, the lidar ratio at $532 \mathrm{~nm}$, the linear particle depolarization ratio at $355 \mathrm{~nm}$ and the extinction-related Ångström exponent from 355 to $532 \mathrm{~nm}$ were $52 \pm 7 \mathrm{sr}, 41 \pm 13 \mathrm{sr}$, $0.9 \pm 0.4 \%$ and $2.3 \pm 0.5$, respectively, for urban/industrial aerosols, while these values were $92 \pm 10 \mathrm{sr}, 75 \pm 14 \mathrm{sr}$, $3.2 \pm 1.3 \%$ and $1.7 \pm 0.3$, respectively, for biomass burn-
\end{abstract}

ing aerosol layers. Biomass burning particles are larger and slightly less absorbing compared to urban/industrial aerosols. The particle effective radius were found to be $0.10 \pm 0.03$, $0.17 \pm 0.04$ and $0.13 \pm 0.03 \mu \mathrm{m}$ for urban/industrial, biomass burning, and mixed aerosols, respectively, while the singlescattering albedo at $532 \mathrm{~nm}$ was $0.87 \pm 0.06,0.90 \pm 0.06$, and $0.88 \pm 0.07$ (at $532 \mathrm{~nm}$ ), respectively, for these three types of aerosols. Our results were within the same range of previously reported values.

\section{Introduction}

Atmospheric aerosols of natural and anthropogenic origin contribute substantially to global climate variability (IPCC, 2013). Currently, the magnitude of the (anthropogenic) aerosol impact on climate causes the largest uncertainty in our knowledge of climate change (Forster et al., 2007). Large uncertainties exist due to the diversity, not only with respect to aerosol particle size, composition, sources and lifetime variation but also with regard to the spatial and temporal distributions of aerosols. Thus, the impacts of aerosols on climate must be understood and quantified on a regional scale rather than on a global-average basis (Piketh et al., 2002).

High-quality aerosol measurements in the Southern Hemisphere are rather limited. South Africa is located at the south- 
ernmost tip of the African continent, extending from 22 to $34^{\circ} \mathrm{S}$ latitude and from 16 to $32^{\circ} \mathrm{E}$ longitude. Previous studies have indicated that South Africa is one of the countries in the world that is largely affected by aerosol load, due to various natural and anthropogenic sources (Piketh et al., 2000, 2002; Formenti et al., 2002, 2003; Campbell et al., 2003; Eck et al., 2003; Freiman and Piketh, 2003; Ichoku et al., 2003; Ross et al., 2003; Winkler et al., 2008; Queface et al., 2011; Tesfaye et al., 2011; Venter et al., 2012; Tiitta et al., 2014). Intensive efforts have been undertaken during recent years to characterize aerosol pollution in South Africa. In general, previous studies pointed at the importance of regional circulation of air masses and seasonal pollutant variation. The optical properties of aerosols have been studied by means of sun photometers (e.g. Queface et al., 2011; Eck et al., 2003), in situ data (e.g. Laakso et al., 2012) and satellite observations (e.g. Tesfaye et al., 2011) in these studies, which are based on columnar aerosol optical properties. Groundbased Raman lidars provide vertically resolved information on the distribution and optical properties of aerosols. Giannakaki et al. (2015) used Raman lidar data obtained over a 1-year period at Elandsfontein in South Africa $\left(26^{\circ} 15^{\prime} \mathrm{S}\right.$, $29^{\circ} 26^{\prime} \mathrm{E}, 1745 \mathrm{~m}$ above sea level, a.s.l.) to study the geometrical characteristics and intensive and extensive optical properties of free-tropospheric aerosol layers. In addition to these characteristics that can be determined with lidar data, multiwavelength Raman lidar measurements can also be used to determine profiles of microphysical particle properties by using inversion algorithms (Twomey, 1977; Veselovskii et al., 2002; Müller et al., 2001). In this study we expand our study of aerosols in South Africa by providing information on the microphysical and optical properties of aerosol layers. These types of aerosol lidar observations are valuable for spaceborne lidars such as CALIPSO (Cloud-Aerosol Lidar and Infrared Pathfinder Satellite Observations) (e.g. Omar et al., 2009), since lidar ratio values for different aerosol types are required for reliable aerosol extinction retrievals. Therefore, this study could be useful for further improving lidar ratio selection-scheme algorithms used in spaceborne lidar missions.

Four long-term ground-based aerosol measurements were carried out at sites in economically growing countries in Asia, Africa and South America within the EUCAARI project (Kulmala et al., 2011), which included Elandsfontein in South Africa. The aim of EUCAARI was to characterize particles in terms of physical, optical and chemical aerosol properties. Here we report lidar observations that were performed at Elandsfontein. In particular, we discuss the optical and microphysical properties of aerosol layers that are caused by biomass burning and urban/industrial activities at the site. We present aerosol lidar ratios, particle linear depolarization ratios and Ångström exponents for biomass burning and urban/industrial aerosol layers measured with a multi-wavelength Raman lidar. The possible effect of desert dust particles on biomass burning aerosol layers in terms

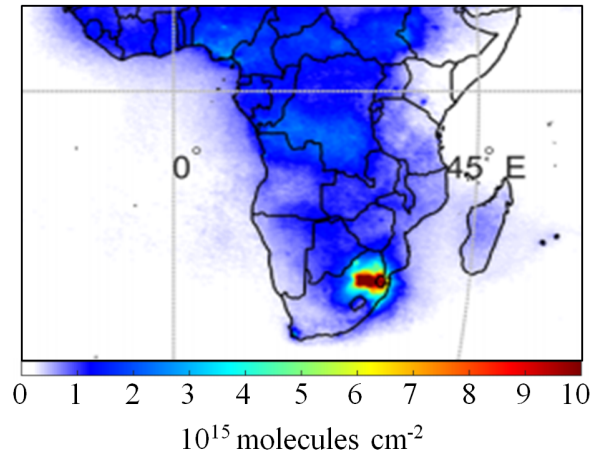

Figure 1. Global map of long-term average tropospheric $\mathrm{NO}_{2}$ column derived from SCIAMACHY data from August 2002 to March 2012 (Schneider et al., 2015).

of the intensive optical and microphysical properties is also addressed. In addition, effective radius and single-scattering albedo are calculated with an advanced inversion algorithm.

The paper is organized as follows. In Sect. 2, the research site, the methodology used for the retrieval of optical and microphysical properties, and the aerosol typing are introduced. As a case study, the arrival of a biomass burning aerosol layer over Elandsfontein is discussed in Sect. 3. Section 4 presents the main findings of the optical and microphysical aerosol properties for selected biomass burning, urban/industrial and mixed aerosol layers. We close our contribution with a summary and conclusion in Sect. 5.

\section{Location and methodology}

\subsection{Measurement site}

The measurement site was located on a hilltop at Elandsfontein $\left(26^{\circ} 15^{\prime} \mathrm{S}, 29^{\circ} 26^{\prime} \mathrm{E} ; 1745 \mathrm{~m}\right.$ a.s.l.) in the Highveld region of South Africa. The station was located approximately $150 \mathrm{~km}$ east of the Johannesburg-Pretoria megacity, which is the largest metropolitan area in South Africa, with a population of more than 10 million people (Lourens et al., 2012).

In South Africa, anthropogenic atmospheric emissions are predominantly the product of industrial activities and biomass burning (Ross et al., 2003). South Africa is the most industrialized country of the continent - primarily due to the industrialized Highveld region (Freiman and Piketh, 2003; Wenig et al., 2003). This region has clusters of industrial complexes and power plants between $25.5^{\circ} \mathrm{S}, 27.5^{\circ} \mathrm{E}$ and $27.0^{\circ} \mathrm{S}, 30.5^{\circ} \mathrm{E}$ (Ross et al., 2003), which contributes significantly to aerosol and trace gases pollution (Freiman and Piketh, 2003). Tropospheric $\mathrm{NO}_{2}$ distributions derived with SCIAMACHY (SCanning Imaging Absorption spectroMeter for Atmospheric CHartographY) from August 2002 to March 2012 (Schneider et al., 2015) are presented in Fig. 1. The tropospheric $\mathrm{NO}_{2}$ column density of the Highveld region in South Africa is comparable to that observed over central 

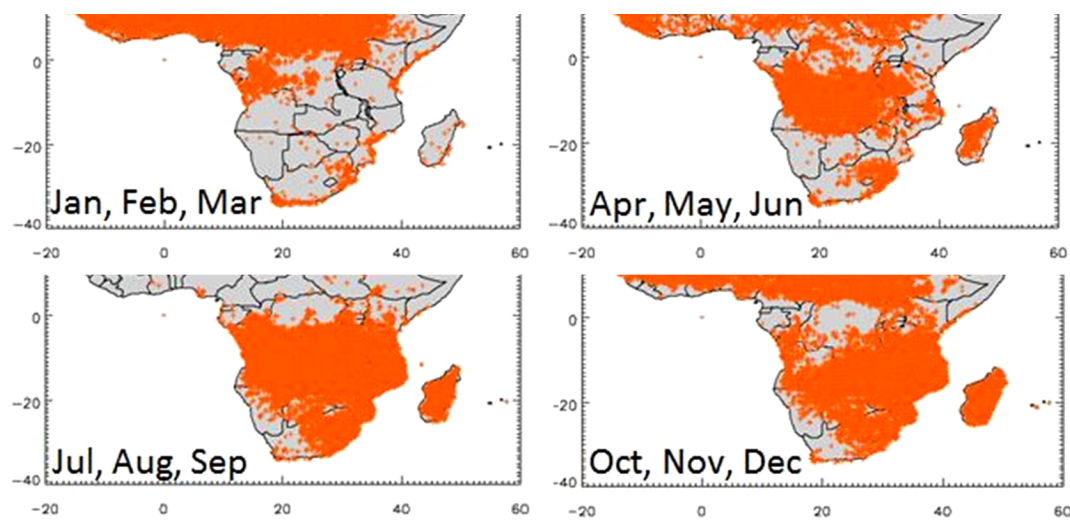

Figure 2. Number of fire hotspots with confidence levels between 80 and $100 \%$ averaged in terms of 3 months for the year 2010 in the latitude range between -40 and $10^{\circ}$ and longitude range between -20 and $60^{\circ}$.

and northern Europe, eastern North America and Southeast Asia (Lourens et al., 2012).

In addition, emissions from biomass burning (wild fires) contribute significantly to regional emission loads (e.g. Giannakaki et al., 2015). Both natural phenomena (lightning) and human-induced activities are responsible for biomass burning (Edwards et al., 2006). The number of hotspots, with confidence levels between 80 and $100 \%$ (http://earthdata.nasa. gov/data/nrt-data/firms/active-fire-data), in the latitude range between -40 and $10^{\circ}$ and longitude range between -20 and $60^{\circ}$ are plotted in Fig. 2. The number of hotspots is averaged in terms of 3 months for the year 2010. Wild fires originate in the subequatorial central African region and progress southward (Roy et al., 2005). In southern Africa, the fires progress along a north-west to south-east track.

\subsection{Description of the lidar system and lidar data processing}

The transportable aerosol Raman lidar Polly ${ }^{\mathrm{XT}}$ that was operated remotely at Elandsfontein is described by Althausen et al. (2009) and Engelmann et al. (2016). Polly ${ }^{\mathrm{XT}}$ works with a Nd:YAG laser emitting at its primary wavelength of $1064 \mathrm{~nm}$, which after frequency doubling and tripling emits at the wavelengths of 532 and $355 \mathrm{~nm}$, respectively. The receiver consists of a Newtonian telescope with a diameter of $300 \mathrm{~mm}$ and a field of view of $1 \mathrm{mrad}$. Photomultiplier tubes are used for the detection of the elastically backscattered photons at 355, 532 and $1064 \mathrm{~nm}$, as well as the inelastically backscattered photons at 387 and $607 \mathrm{~nm}$ that correspond to the Raman shift by nitrogen molecules at 355 and $532 \mathrm{~nm}$, respectively. Additionally, the cross-polarized component at $355 \mathrm{~nm}$ is detected and consequently allows for the determination of the linear particle depolarization ratio (also called depolarization ratio). To retrieve the particle depolarization ratio the Rayleigh calibration method was applied within the data analysis under the assumption of pure Rayleigh depolarization in an aerosol-free height range (Behrendt and Naka- mura, 2002). The vertical resolution of the signal profiles is $30 \mathrm{~m}$ and the raw data are typically stored as $30 \mathrm{~s}$ average values $(20 \mathrm{~Hz}$ laser frequency). Data were collected on the web page of PollyNet (http://polly.tropos.de) where the "quicklooks" of all measurements are available.

Extinction and backscatter coefficient profiles at 355 and $532 \mathrm{~nm}$, respectively, were obtained with the Raman method (Ansmann et al., 1992). To vertically retrieve the backscatter coefficient at $1064 \mathrm{~nm}$ we use the Fernald-Klett method (Fernald, 1984; Klett, 1981). With this method the particle backscatter coefficient is derived applying a backward iteration starting at a chosen reference height. The method requires independent information on the lidar ratio and on the reference value of the particle backscatter coefficient. The cases analysed here are night-time measurements and the retrieved backscatter at $1064 \mathrm{~nm}$ was also evaluated by the Raman method (Ansmann et al., 1992) using also the signal from the nitrogen Raman channel at the $607 \mathrm{~nm}$. An overlap correction was applied on the basis of a simple technique proposed by Wandinger and Ansmann (2002). The depolarization ratio, i.e. the ratio of the cross-polarized to the parallelpolarized component of the backscatter coefficient (particles and molecules) at $355 \mathrm{~nm}$, was also calculated. The contribution of the molecules can easily be calculated, which then provides the linear particle depolarization ratio (Cairo et al., 1999; Murayama et al., 1999).

The uncertainties affecting the retrieval of extinction and backscatter coefficients, and thus the calculation of lidar ratio and Ångström exponents are mainly due to the statistical error owing to signal detection, the systematic error associated with the estimation of the atmospheric molecular number density from the pressure and temperature profiles, the systematic error associated with the evaluation of the aerosol scattering wavelength dependence, the systematic error for overlap function, the errors introduced by operation procedure such as signal binning (smoothing) and averaging accumulating lidar returns. The overall relative errors of the lidarderived aerosol properties range between 5 and $15 \%$ for the 
backscatter coefficients, 10 and $30 \%$ for the extinction coefficients, 20 and $40 \%$ for the Ångström exponents, 15 and $40 \%$ for the lidar ratios and approximately 5 and $10 \%$ for the linear particle depolarization ratio (Hänel et al., 2012; Baars et al., 2016; Engelmann et al., 2016). A detailed discussion on the influence of aerosol optical depth errors to Ångström exponent errors can be found in Wagner and Silva (2008).

The layer identification was based on the assumption that the optical properties should be relatively stable. This means that within a chosen height layer, the variability in the optical data should be less than the statistical uncertainty in the individual data points.

In Table 1 we provide information regarding the elevated layers that were selected for the optical and microphysical aerosol characterization. The characterization of aerosol types will be discussed in Sect. 2.4.

\subsection{Retrieval of microphysical properties}

Microphysical particle properties are derived with an inversion algorithm that has been developed at the Leibniz Institute for Tropospheric Research. A detailed description of the inversion code is given by Müller et al. (1999a, b). A minimum of three backscatter coefficients $(355,532$, and $1064 \mathrm{~nm})$ and two extinction coefficients ( 355 and $532 \mathrm{~nm}$ ), with measurement errors less than $30 \%$, are required as input in order to obtain microphysical results that have reasonably low uncertainties (Müller et al., 2001). The selection of the individual inversion solutions is based on the concept that the back-calculated optical data should agree with the original data within the limits of the measurement errors, and that a pre-selected discrepancy level, which is an output parameter of the inversion algorithm (Müller et al., 1999a), is not exceeded. The mean particle size in terms of the effective radius is then calculated along with the standard deviation from these selected individual solutions. One also obtains a range of complex refractive indexes by applying this method. The complex refractive index is a wavelength-independent quantity. Therefore, inversion can only provide a wavelengthindependent value that represents the entire range of wavelengths from 355 to $1064 \mathrm{~nm}$. The single-scattering albedo can then be calculated from the volume concentration distribution, which is another data product of the inversion algorithm, and the associated mean complex refractive index by means of a Mie scattering algorithm.

Uncertainties associated with the retrievals are in general $<30 \%$ for effective radius. The real part of the complex refractive index is derived to an accuracy better than \pm 0.1 , while the imaginary part is obtained for its correct order of magnitude if the value is $<0.01 i$ (for larger values of the imaginary part the uncertainty is $<50 \%$ ). The single-scattering albedo can be calculated with an accuracy of \pm 0.05 if uncertainties of the input optical data are on average $<10-15 \%$. A detailed error analysis is presented by
Müller et al. (1999b, 2001) and Veselovskii et al. (2002, 2004).

\subsection{Aerosol classification}

The identification of the source of aerosol particles is possible with the synergetic use of in situ and satellite measurements, as well as utilizing model estimations.

The HYSPLIT_4 (Hybrid Single Particle Lagrangian Integrated Trajectory) model (Draxler and Hess, 1997) was used to compute backward air mass trajectories employing the kinematic approach and by using the re-analysed National Oceanic and Atmospheric Administration (NOAA) dataset with a resolution of $2.5^{\circ} \times 2.5^{\circ}$ (latitude, longitude) as input. Four-day backward trajectories were selected because they extend far enough back in time and distance to cover the main source regions suspected to affect the region investigated. The trajectories were calculated for the centre of the layer observed and for the time of the lidar measurement.

The number of fire hotspots is given by Moderate Resolution Imaging Spectroradiometer (MODIS) collection-5 active-fire product data (Giglio et al., 2010). The number of hotspots, obtained from MODIS for 4 days prior to each of the measurements, was superimposed on the trajectory analysis map in order to detect the presence of smoke particles over our site for the cases analysed.

Trace gases were measured as part of routine air quality monitoring at the site by the national electricity supplier, i.e. Eskom. A Thermo Electron $43 \mathrm{C} \mathrm{SO}_{2}$ analyser and a Thermo Electron $42 \mathrm{i} \mathrm{NO}_{x}$ analyser were used to measure $\mathrm{SO}_{2}$ and $\mathrm{NO}_{x}$, respectively. $\mathrm{H}_{2} \mathrm{~S}$ was measured with a Thermo Electron $43 \mathrm{~A} \mathrm{SO}_{2}$ analyser with a Thermo Electron 340 converter. Fifteen-minute data were averaged for the extent of measurement time for each of the measurements periods (Table 1). For instances where the combined use of trajectory analysis and fire hotspots did not indicate the presence of biomass burning aerosols we checked whether the measured $\mathrm{NO}_{x}, \mathrm{SO}_{2}$ or $\mathrm{H}_{2} \mathrm{~S}$ concentrations were higher than the seasonal mean values of that measured for the entire period of the EUCAARI campaign. These seasonal mean values are presented in Laakso et al. (2012). In addition, when the trace gases concentrations were lower than the mean seasonal values measured during the EUCAARI campaign and biomass burning activity or desert dust advection were absent, we checked whether the daily concentration of the trace gases exceeded the mean critical values.

There were also cases that indicated desert dust aerosol particles in addition to the smoke, which originated from either the Kalahari or Namib desert and could have additionally contributed to the aerosol loads. Therefore, the measured aerosol optical properties determined for these cases were attributed to a mixing state where smoke particles were possible to be mixed with desert dust aerosols. Additional mixing with urban/industrial aerosols is also possible. 
Table 1. Aerosol type, time and altitude range of aerosol layers used for optical and microphysical aerosol characterization.

\begin{tabular}{|c|c|c|c|c|c|}
\hline \multirow[t]{2}{*}{ Aerosol source } & \multirow[t]{2}{*}{ Date } & \multirow[t]{2}{*}{ Time [UTC] } & \multirow[t]{2}{*}{ eight $[\mathrm{m}]$} & \multicolumn{2}{|c|}{ Extinction coefficient $\left[\mathrm{Mm}^{-1}\right]$} \\
\hline & & & & $355 \mathrm{~nm}$ & $532 \mathrm{~nm}$ \\
\hline \multirow[t]{17}{*}{ Urban/industrial } & 25 March 2010 & 18:00-19:50 & $2100-2670$ & $196 \pm 18$ & $75 \pm 12$ \\
\hline & 25 March 2010 & $18: 00-19: 50$ & $2790-3450$ & $190 \pm 36$ & $68 \pm 14$ \\
\hline & 25 March 2010 & $18: 00-19: 50$ & $1560-1980$ & $260 \pm 6$ & $78 \pm 12$ \\
\hline & 16 April 2010 & $21: 20-23: 54$ & $1980-2250$ & $147 \pm 13$ & $58 \pm 9$ \\
\hline & 16 April 2010 & $21: 20-23: 54$ & $2280-2520$ & $129 \pm 10$ & $39 \pm 4$ \\
\hline & 16 April 2010 & $21: 20-23: 54$ & $2610-3180$ & $196 \pm 43$ & $81 \pm 14$ \\
\hline & 14 May 2010 & 18:00-00:00 & $930-1360$ & $238 \pm 37$ & $127 \pm 25$ \\
\hline & 15 May 2010 & $18: 30-20: 20$ & $1380-1860$ & $196 \pm 26$ & $86 \pm 19$ \\
\hline & 15 May 2010 & $18: 30-20: 20$ & $2250-2700$ & $81 \pm 7$ & $28 \pm 3$ \\
\hline & 30 November 2010 & $17: 15-18: 00$ & $960-1300$ & $121 \pm 6$ & $44 \pm 13$ \\
\hline & 30 November 2010 & $17: 15-18: 00$ & $1350-1920$ & $146 \pm 26$ & $50 \pm 11$ \\
\hline & 30 June 2010 & $17: 00-18: 00$ & $1420-1620$ & $101 \pm 5$ & $34 \pm 5$ \\
\hline & 30 June 2010 & 17:00-18:00 & $1650-1830$ & $71 \pm 11$ & $37 \pm 7$ \\
\hline & 10 January 2011 & $19: 15-20: 15$ & $1890-2160$ & $303 \pm 45$ & $146 \pm 31$ \\
\hline & 13 January 2011 & $21: 00-22: 00$ & $1200-1800$ & $342 \pm 24$ & $163 \pm 17$ \\
\hline & 13 January 2011 & $21: 00-22: 00$ & $1920-2250$ & $267 \pm 42$ & $158 \pm 29$ \\
\hline & 13 January 2011 & 21:00-22:00 & $2430-2880$ & $199 \pm 23$ & $68 \pm 12$ \\
\hline \multirow[t]{14}{*}{ Biomass burning } & 1 October 2010 & 00:10-01:00 & $1090-1900$ & $331 \pm 9$ & $158 \pm 8$ \\
\hline & 5 October 2010 & $18: 10-23: 10$ & $1115-1750$ & $432 \pm 62$ & $227 \pm 37$ \\
\hline & 5 October 2010 & $18: 10-23: 10$ & $1980-2700$ & $256 \pm 18$ & $132 \pm 15$ \\
\hline & 6 October 2010 & 20:00-00:00 & $1175-1540$ & $277 \pm 27$ & $142 \pm 5$ \\
\hline & 6 October 2010 & 20:00-00:00 & $1565-2160$ & $214 \pm 14$ & $111 \pm 11$ \\
\hline & 6 October 2010 & 20:00-00:00 & $2190-2520$ & $152 \pm 6$ & $85 \pm 16$ \\
\hline & 6 October 2010 & 20:00-00:00 & $2610-2820$ & $121 \pm 19$ & $80 \pm 6$ \\
\hline & 21 October 2010 & $01: 30-02: 30$ & $880-1530$ & $261 \pm 28$ & $131 \pm 20$ \\
\hline & 21 October 2010 & $01: 30-02: 30$ & $1685-2280$ & $168 \pm 7$ & $66 \pm 16$ \\
\hline & 21 October 2010 & $01: 30-02: 30$ & $2400-2880$ & $171 \pm 30$ & $70 \pm 14$ \\
\hline & 22 August 2010 & 00:00-01.00 & $1205-1565$ & $340 \pm 13$ & $162 \pm 8$ \\
\hline & 22 August 2010 & 00:00-01.00 & $1685-1920$ & $354 \pm 5$ & $190 \pm 8$ \\
\hline & 22 August 2010 & 02:00-03:00 & $1115-1535$ & $335 \pm 6$ & $163 \pm 10$ \\
\hline & 22 August 2010 & 02:00-03:00 & $1745-2250$ & $331 \pm 15$ & $170 \pm 4$ \\
\hline \multirow[t]{7}{*}{ Mixed aerosols } & 16 August 2010 & 17:00-18:00 & $1115-1445$ & $316 \pm 24$ & $151 \pm 9$ \\
\hline & 16 August 2010 & 19:00-20:00 & $995-1265$ & $296 \pm 7$ & $157 \pm 11$ \\
\hline & 18 August 2010 & 19:00-20:00 & $1175-1355$ & $154 \pm 9$ & $75 \pm 4$ \\
\hline & 18 August 2010 & 19:00-20:00 & $1415-1715$ & $174 \pm 11$ & $66 \pm 4$ \\
\hline & 18 August 2010 & 19:00-20:00 & $1865-2160$ & $184 \pm 6$ & $66 \pm 3$ \\
\hline & 22 August 2010 & 17:00-18:00 & $1145-1505$ & $286 \pm 3$ & $109 \pm 4$ \\
\hline & 22 August 2010 & $17: 00-18: 00$ & $1595-2040$ & $267 \pm 16$ & $119 \pm 8$ \\
\hline
\end{tabular}

An example of a measurement of biomass burning aerosols is discussed in the subsequent section in order to demonstrate the methodology used to derive the optical and microphysical aerosol properties.

\section{Biomass burning aerosols on 1 October 2010 at Elandsfontein, South Africa}

In this section we will study a geometrically deep layer that extends up to $2.1 \mathrm{~km}$ height above ground level (a.g.l.) as observed on 1 October 2010. The atmospheric structure, in terms of range corrected signals, is quite stable, which indicates similar optical properties throughout the layer (http://polly.tropos.de/?p=bilder\&lambda= $1064 \& \mathrm{Jahr}=2010 \&$ Monat $=10 \& \mathrm{Tag}=1 \&$ Ort $=11$ \#bildanker).

High backscatter returns are observed on the day when the measurement is conducted in relation to the previous and the next day (as can be already seen in Fig. 4a - light green).

MODIS fire hotspots product reveal that several fires were active during the period 28 September 2010-1 October 2010 as shown in Fig. 3a. In Fig. 3b, 4-day backward trajectories arriving at Elandsfontein on 1 October 2010 

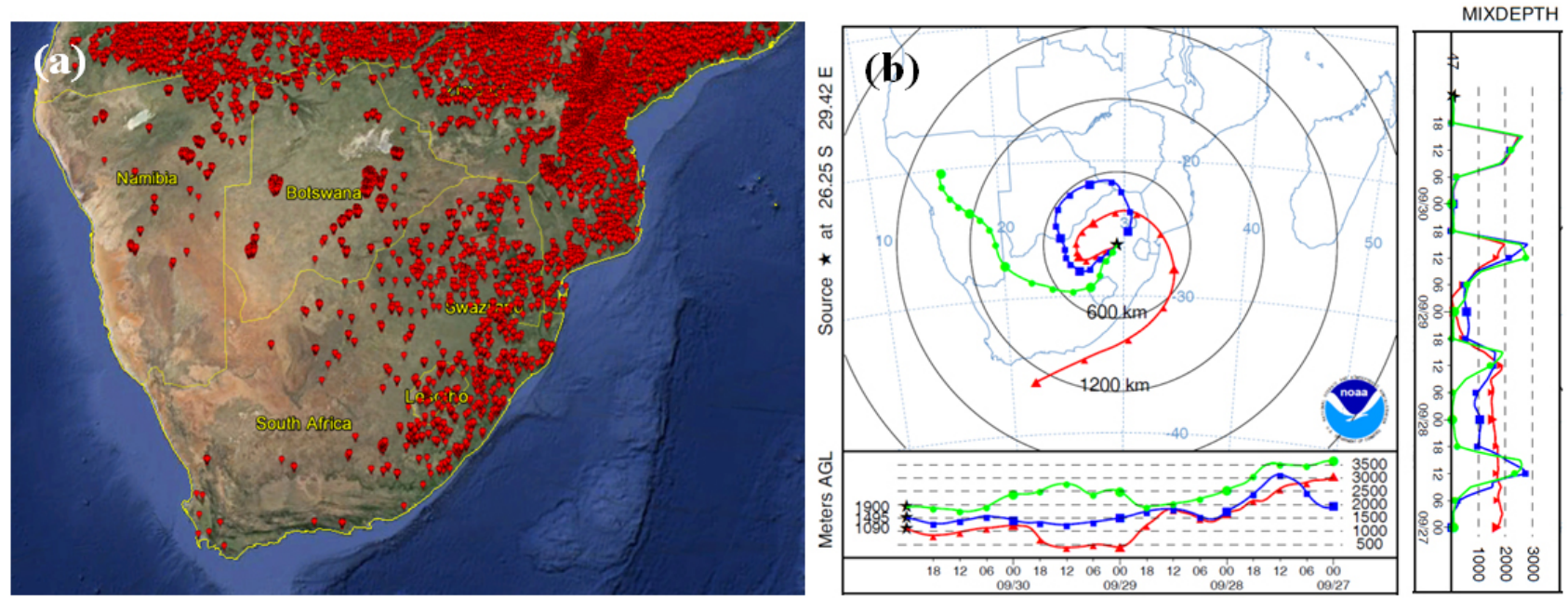

Figure 3. MODIS fire hotspots for the period 28 September $2010-1$ October 2010 and for the latitude range between -35 and $-15^{\circ} \mathrm{W}$ and the longitude range between 10 and $40^{\circ} \mathrm{S}$ (a). Four-day backward trajectories arriving at Elandsfontein on 1 October 2010 at 00:00 UTC for arrival height of the bottom $(1090 \mathrm{~m})$, centre $(1495 \mathrm{~m})$ and top $(1900 \mathrm{~m})$ of the aerosol layer observed (b).
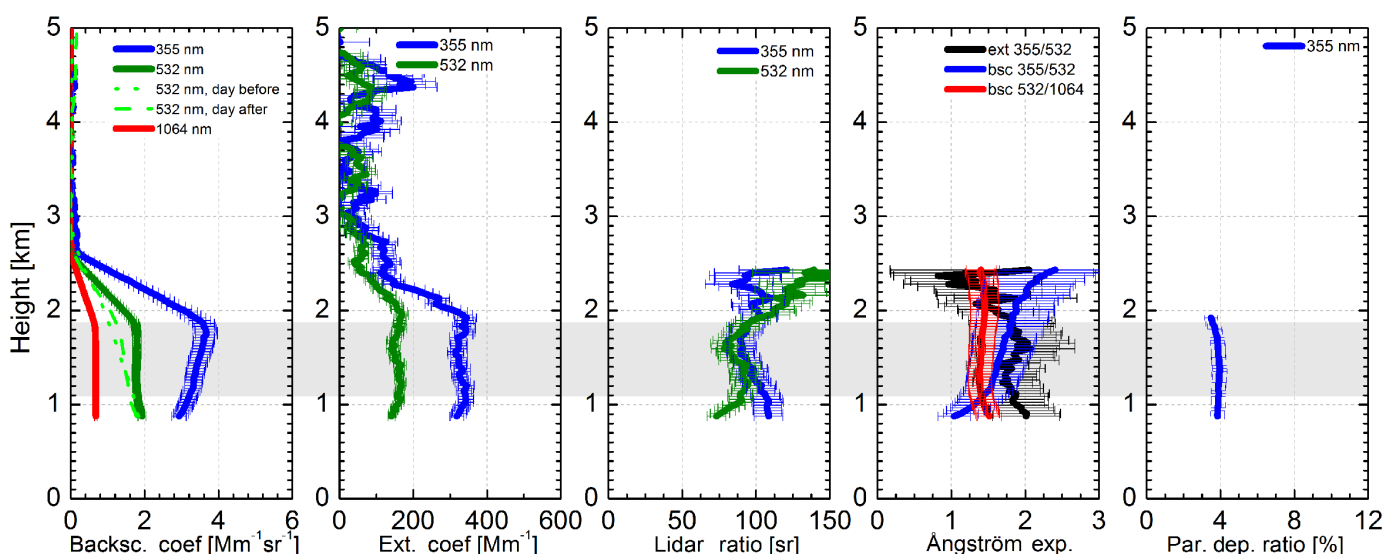

Figure 4. Backscatter coefficients, extinction coefficients, lidar ratios, Ångstrom exponents and particle depolarization ratio at Elandsfontein on 1 October 2010, 00:10-03:59 UTC.

at 00:00 UTC are presented. The trajectories are computed for arrival heights of the bottom, centre and top of the observed layer. The trajectory analysis along with MODIS fire hotspots reveals that it is highly possible that the air masses carry smoke particles at Elandsfontein on the day of the measurement.

In Fig. 4 the optical lidar profiles are presented. The backscatter and extinction maximum at all three wavelengths were observed within the 0.9 to $1.9 \mathrm{~km}$ height range. High values of the lidar ratio of $96 \pm 5 \mathrm{sr}$ at $355 \mathrm{~nm}$ and $89 \pm 5 \mathrm{sr}$ at $532 \mathrm{~nm}$ indicate that the smoke particles inside this layer were most likely highly light-absorbing. The Ångström exponent, related to extinction between 355 and $532 \mathrm{~nm}$, was $1.8 \pm 0.1$, which points to comparably small particles and indicative of fresh smoke (e.g. Müller et al., 2005). A constant particle depolarization ratio in the order of $4 \%$ is ob- served at $355 \mathrm{~nm}$ throughout the layer. The lack of significant vertical variability in the lidar ratio, the Ångström exponent and the particle depolarization ratio suggests the presence of the same type (biomass burning) of aerosols throughout the layer.

The mean values of extinction (at 355 and $532 \mathrm{~nm}$ ) and backscatter coefficients (at 355, 532 and $1064 \mathrm{~nm}$ ) were calculated within the defined layer and were used as input in the inversion algorithm. Effective radius, complex refractive index and single-scattering albedo were calculated with the microphysical inversion code. An effective radius of $0.15 \pm 0.02 \mu \mathrm{m}$ was determined, while the single-scattering albedo was approximately 0.86 at $532 \mathrm{~nm}$ that indicates relatively strong absorbing aerosols. 


\section{Results and discussion}

We performed optical lidar data analysis, microphysical retrievals and aerosol typing for each of the 38 aerosol layers listed in Table 1 in the same way as presented in the example in Sect. 3. Each aerosol layer in Table 1 was classified into one of the three aerosol types, i.e. urban/industrial, biomass burning, and mixed aerosols after thorough visual inspection of the backward trajectories, MODIS hotspot fire products and in situ aerosol observations, as explained in Sect. 2.4. Table 2 summarizes the mean intensive optical properties (lidar ratio at 355 and $532 \mathrm{~nm}$, depolarization ratio at $355 \mathrm{~nm}$ and Ångström exponent related to extinction between 355 and $532 \mathrm{~nm}$ ) presented together with the associated standard deviations, ranges (minimum and maximum values) and medians.

Figure 5 presents the particle lidar ratios at $355 \mathrm{~nm}$ vs. the extinction-related Ångström exponent for urban/industrial (black), biomass burning (red) aerosol layers and the mixed aerosol layers (green). Different aerosol types occupy different areas in the Ångström exponent-lidar ratio plot. Aerosols from urban and industrial activities are on average characterized by larger Ångström exponents than (pure or mixed) biomass burning aerosols. The lidar ratios of biomass burning aerosols are among the highest compared to the literature, with a mean value of $92 \pm 10 \mathrm{sr}$ (e.g. Müller et al., 2007; Nicolae et al., 2013; Amiridis et al., 2009). Urban/industrial aerosol layers were found to have lower lidar ratio values in the range between 41 and $59 \mathrm{sr}$ at $355 \mathrm{~nm}$. Our results indicate that biomass burning aerosols have lower lidar ratios when they are mixed with either desert dust aerosols or urban/industrial aerosols. This might be due to the nonspherical shape of desert dust, which may have a significant effect on the lidar ratio. Model calculations show that a deviation from the spherical shape can efficiently increase particle backscattering and thus lower the lidar ratio (Mishchenko et al., 1997), which was also confirmed by Müller et al. (2003). Angström exponent values of these aerosols ranged from 1.6 to 2.5 , with a mean value of $2.0 \pm 0.4$, which is larger (smaller particles) than the mean value of $1.7 \pm 0.3$ we observed for "pure" biomass burning aerosols. The role that hot air close to the surface of the earth plays in generating these dust size distribution is not well understood (Nisantzi et al., 2014). Wind stress close to the surface may be very complex, and the sudden release of all the moisture in the hot soil particles may strongly influence the breaking of larger particles into smaller ones and thus lead to a much more complicated size distribution than observed during desert dust outbreaks (Mamouri and Ansmann, 2014).

It is evident from Fig. 5 that Ångström exponent values for the different aerosol types overlap. Therefore, another intensive aerosol property, the linear particle depolarization ratio, which is an indicator of non-spherical particles, was also used. Figure 6 shows the lidar ratio at $355 \mathrm{~nm}$ vs. the depolarization ratio at the same wavelength for the three aerosol
Table 2. Mean value \pm standard deviation of aerosol lidar ratio at 355, particle depolarization ratio and Ångström exponent related to extinction between 355 and $532 \mathrm{~nm}$ for the examined aerosol types, as well as value of range and median.

\begin{tabular}{lrcc}
\hline Aerosol source & Mean \pm SD & Range & Median \\
\hline \multicolumn{4}{c}{ lidar ratio at 355 nm [sr] } \\
\hline Urban/industrial & $52 \pm 7$ & $41-59$ & 54 \\
Biomass burning & $92 \pm 10$ & $81-119$ & 88 \\
Mixed aerosols & $74 \pm 11$ & $59-90$ & 73 \\
\hline \multicolumn{4}{c}{ lidar ratio at 532 nm [sr] } \\
\hline Urban/industrial & $41 \pm 13$ & $23-74$ & 38 \\
Biomass burning & $75 \pm 14$ & $47-92$ & 79 \\
Mixed aerosols & $46 \pm 13$ & $33-68$ & 40 \\
\hline \multicolumn{4}{c}{ Particle depolarization ratio at 355 nm [\%] } \\
\hline Urban/industrial & $0.9 \pm 0.4$ & $0.3-1.7$ & 1.0 \\
Biomass burning & $3.2 \pm 1.3$ & $1.2-5.7$ & 2.7 \\
Mixed aerosols & $8.3 \pm 0.7$ & $7.3-9.1$ & 8.1 \\
\hline \multicolumn{4}{c}{ Angström exponent related to extinction } \\
between 355 and 532 nm \\
\hline Urban/industrial & $2.3 \pm 0.5$ & $1.3-3.0$ & 2.4 \\
Biomass burning & $1.7 \pm 0.3$ & $1.0-2.4$ & 1.7 \\
Mixed aerosols & $2.0 \pm 0.4$ & $1.6-2.5$ & 2.0 \\
\hline
\end{tabular}

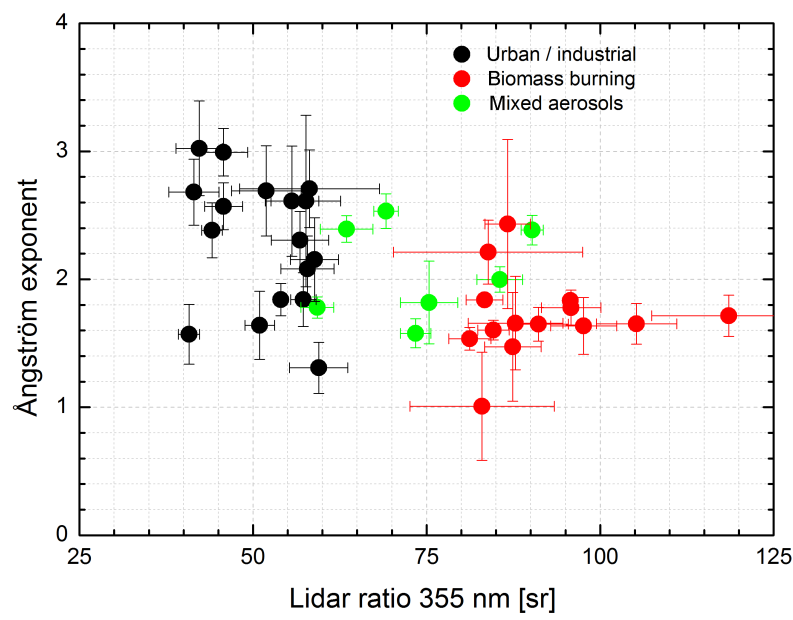

Figure 5. Lidar ratio at $355 \mathrm{~nm}$ vs. the extinction-related Ångström exponent from 355 to $532 \mathrm{~nm}$ for the three aerosol types investigated in our study.

types. Different clusters of data pairs can be identified. Lower depolarization ratio values were found for urban/industrial aerosol layers. These aerosol layers are also characterized by lower lidar ratios and thus the data points representing urban/industrial pollution occupy the lower left region in Fig. 5. Significantly larger particle linear depolarization ratios with a mean of $8.3 \pm 0.7 \%$ were found for mixed aerosols. Typ- 


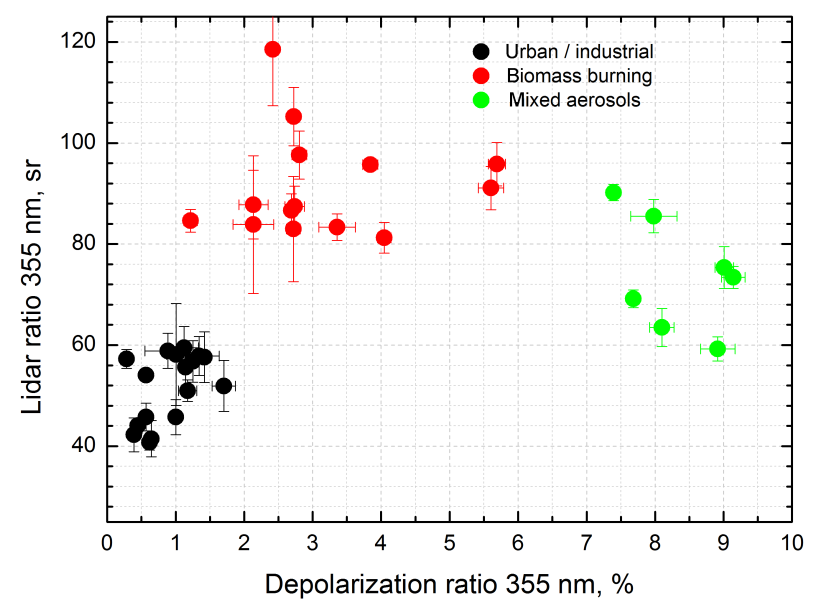

Figure 6. Lidar ratio at $355 \mathrm{~nm}$ vs. the depolarization ratio at $355 \mathrm{~nm}$ for the three aerosol types investigated in our study.

ical desert dust aerosol depolarization ratios determined in field measurements performed in the north-western corner of the Sahara ranged from 30 to $35 \%$ at $532 \mathrm{~nm}$ with a mean value of $31 \pm 3 \%$ (Freudenthaler et al., 2009). In addition, particle depolarization ratios ranging between 30 and $35 \%$ were also observed for Asian desert dust (Sugimoto et al., 2003; Shimizu et al., 2004; Shin et al., 2015) and desert dust originating from Middle East dust sources (Mamouri et al., 2013). Depolarization ratios of the mixtures of biomass burning aerosols and desert dust particles determined for African biomass burning and dust mixtures ranged between 8 and $26 \%$ at $532 \mathrm{~nm}$ (Weinzierl et al., 2011; Tesche et al., 2009). Therefore, depolarization values reported in this study are at the lower end of these values. This observed difference can be attributed to the different contribution of desert dust particles to the biomass burning plume. However, we should also note that the geometrical shape of the dust particles over the Kalahari desert could be different from the shape of Saharan dust. Also, the possible influence of the background urban/industrial aerosols in the mixture should be kept in mind.

A wide range of (lower) depolarization ratios and lidar ratios was found for biomass burning aerosols. This observed variability can be attributed to differences in the chemical composition of the particles that depend on the source region, relative humidity in the atmosphere, the type of fire, or the combined effect of these factors. In addition, the mixing of the biomass burning aerosols with maritime or even urban/industrial background aerosols cannot be excluded as a possible reason for the variability in lidar ratio and depolarization ratio values.

Several statistics of lidar ratios and Ångström exponents for different aerosol types in the world are available for comparison. Figure 7 provides some of the general literature with regard to the lidar ratios values at $355 \mathrm{~nm}$ and Ångström exponents of urban/industrial and biomass burning aerosols, as well as for mixtures of biomass burning and desert dust aerosols. To interpret the $x$ axis of Fig. 7, one should also look at Table 4. It is evident from Fig. 7 that intensive aerosol properties are in good agreement with values found from other studies.

The lidar ratio at $355 \mathrm{~nm}$, in particular, shows similar values for urban/industrial aerosols in various regions of the world. Ångström exponent values found for urban/industrial particles in this study are at the upper limit of results previously published for this aerosol type, which indicates slightly smaller particles at Elandsfontein that can most probably be ascribed to differences in the emission sources. The depolarization ratio is at the lower limit indicating spherically shaped anthropogenic particles.

The lidar ratio for biomass burning aerosol layers is within the range of previously reported values, although the values tend to be more at the upper limit of the reported values. The Ångström exponents are in very good agreement with previous studies. Müller et al. (2007) studied the growth of free-tropospheric forest fire smoke particles and indicated that the Angström exponent decreases with the duration of transport. The Ångström exponent values found in this study $(1.7 \pm 0.3)$ corresponds to travel times of the biomass burning aerosols between 1 and 3 days, which is confirmed by backward trajectory analysis. The characteristics of biomass burning emissions in the subtropical South African region vary according to the type of fuel burned (vegetation type), meteorology and combustion phase (Ross et al., 2003). For example, flaming grass fires produce smoke with more soot compared to smoke emitted from smoldering wood and bush fires (Pósfai et al., 2003). Thus, differences in the chemical composition of the particles might be one of the reasons for the observed large lidar ratio.

For the mixed aerosols the lidar ratio values reported here are in very good agreement with previous studies for the mixture of desert dust and biomass burning aerosols. The contribution of desert dust particles within the observed biomass burning plumes is probably lower, thus resulting in a lower depolarization ratio and larger Ångström exponent than what has been reported in the literature for biomass burning mixed with dust as mentioned previously. Groß et al. (2011) reported neutral wavelength dependence of the particle depolarization ratios for mixed dust and smoke layers for which Ångström exponents varied between 0.12 and 0.16 , while Tesche et al. (2011) reported wavelength-independent linear particle depolarization ratios of $0.12-0.18$ at 355,532 and $710 \mathrm{~nm}$ for mixed dust and smoke layers. In that sense our results on particle depolarization ratios at $355 \mathrm{~nm}$ are similar to results from these studies reporting linear particle depolarization ratio at $532 \mathrm{~nm}$.

In Fig. 8 the effective radius against the Angström exponent is plotted. In general the plot shows the same features already noted for Fig. 5. On average the largest aerosols are determined for biomass burning aerosols (red) with an effective radius of $0.17 \pm 0.04 \mu \mathrm{m}$. Particles from anthropogenic pollution (black) are smaller with a mean effective radius of 

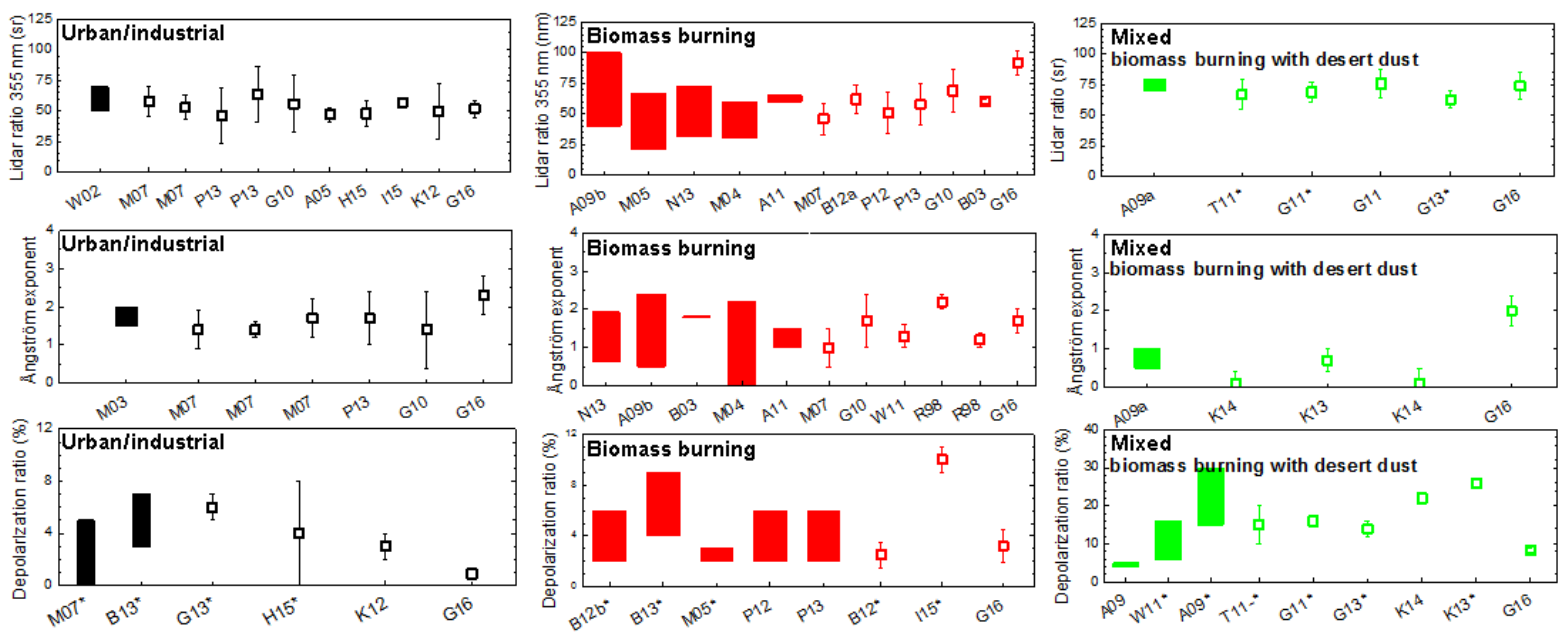

Figure 7. General literature values for lidar ratio at $355 \mathrm{~nm}$, Ångström exponent and depolarization ratio (355 or $532 \mathrm{~nm}$ ) for urban/industrial (black), biomass burning (red) and mixed biomass burning with desert dust aerosols (green). The $x$ axes are the studies presented in Table 4 . Floating columns refer to range values, while the symbols refer to mean values with 1 standard deviation. The depolarization values are at $355 \mathrm{~nm}$ except for the cases noted with an asterisk $\left(^{*}\right)$, which refer to visible wavelength $(532$ or $710 \mathrm{~nm})$.

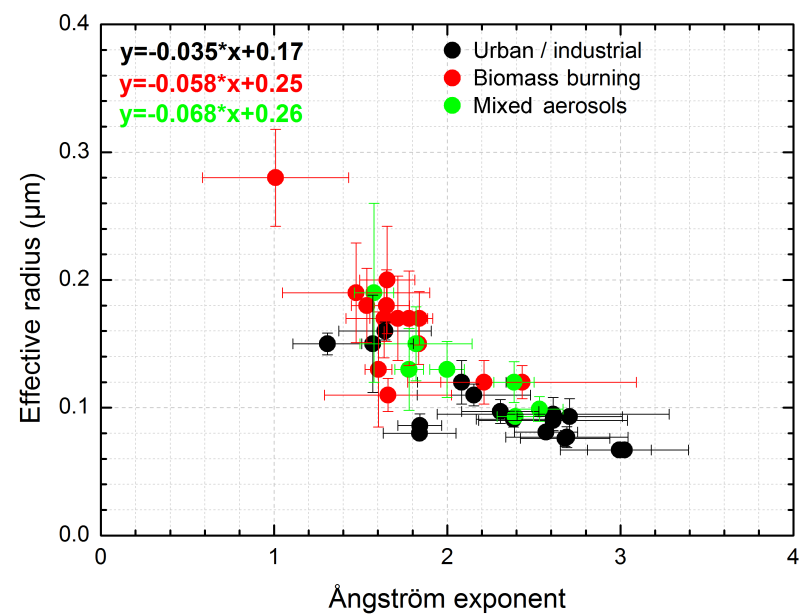

Figure 8. Effective radius vs. Ångström exponent for the three aerosol types investigated in our study.

$0.1 \pm 0.03 \mu \mathrm{m}$. Our results indicate that the influence of Kalahari desert dust on biomass burning plumes leads to smaller particles compared to pure biomass burning aerosols with a mean effective radius of $0.13 \pm 0.03 \mu \mathrm{m}$.

Mean microphysical properties i.e. effective radius, singlescattering albedo and complex refractive index are listed with their associated standard deviations, ranges (minimum and maximum values) and medians in Table 3. The particles in the biomass burning aerosol layers show a mean effective radius of $0.17 \pm 0.04 \mu \mathrm{m}$, which is within the range of values reported in previous studies for biomass burning aerosols. Reid and Hobbs (1998) reported count median diameter values ranging from $0.12 \mu \mathrm{m}$ for fresh particles to
$0.21 \mu \mathrm{m}$ for aged particles near rainforest fires in Brazil. Radke et al. (1988) obtain values of approximately $0.22 \mu \mathrm{m}$ for particles from forest fires in North America. Wandinger et al. (2002) found larger biomass burning aerosols with an effective radius of approximately $0.25 \mu \mathrm{m}$. Effective radii in the range between 0.19 and $0.44 \mu \mathrm{m}$ were found for biomass burning aerosol layers resulting from long-range transport across Romania (Nicolae et al., 2013). Müller et al. (2007) presented values ranging between 0.13 and $0.15 \mathrm{~nm}$ for plumes ageing between 1 and 3 days.

The three types of aerosols cover a wide range of single-scattering albedo values as shown in Table 3. The mean single-scattering albedo for biomass burning aerosol is $0.90 \pm 0.06$ (at $532 \mathrm{~nm}$ ). Lower single-scattering albedos are reported in the literature for fresh biomass burning particles in Europe. Nicolae et al. (2013) reported a value of $0.78 \pm 0.02$, while Reid and Hobbs (1998) found that single-scattering albedo ranges between 0.74 and 0.77 for fresh smoke. Previous studies show that aged biomass burning layers are characterized by larger single-scattering albedos. For example, Murayama et al. (2004) found a value of $0.95 \pm 0.06$ at $532 \mathrm{~nm}$, while Noh et al. (2009) reported single-scattering albedos of 0.92 at the same wavelength. Therefore our results indicate moderately absorbing particles resulting from fresh or medium-aged (less than 3 days) biomass burning aerosols.

For the mixed aerosols we determined lower mean scattering albedos of $0.88 \pm 0.07$, which is slightly higher than the mean single-scattering albedo of $0.87 \pm 0.06$ determined for urban/industrial aerosol layers. Laakso et al. (2012) reported values of $0.84 \pm 0.08(637 \mathrm{~nm})$ at ground level at Elandsfontein, South Africa. Queface et al. (2011) determined significantly larger values of 0.91 and 0.89 at 440 
Table 3. Mean value \pm standard deviation of effective radius and single-scattering albedo for the examined aerosol types, as well as range and median. RRI: real refractive index; IRI: imaginary refractive index.

\begin{tabular}{lcrr}
\hline Aerosol source & Mean \pm SD & Range & Median \\
\hline \multicolumn{4}{c}{ effective radius $[\mu \mathrm{m}]$} \\
\hline Urban/industrial & $0.10 \pm 0.03$ & $0.07-0.16$ & 0.09 \\
Biomass burning & $0.17 \pm 0.04$ & $0.11-0.28$ & 0.17 \\
Mixed aerosols & $0.13 \pm 0.03$ & $0.09-0.19$ & 0.13 \\
\hline & single-scattering albedo at 532 nm & \\
\hline Urban/industrial & $0.87 \pm 0.06$ & $0.75-0.96$ & 0.88 \\
Biomass burning & $0.90 \pm 0.06$ & $0.77-0.98$ & 0.90 \\
Mixed aerosols & $0.88 \pm 0.07$ & $0.76-0.95$ & 0.89 \\
\hline & complex refractive index & & \\
\hline Urban/industrial & $1.61( \pm 0.11)+0.021( \pm 0.010) i$ & $1.47-1.78(\mathrm{RRI})$ & $1.64(\mathrm{RRI})$ \\
Biomass burning & $1.43( \pm 0.07)+0.016( \pm 0.011) i$ & $1.35-1.57(\mathrm{RRI})$ & 1.40 (RRI) \\
& & $0.002-0.046(\mathrm{RRI})$ & 0.015 (IRI) \\
Mixed aerosols & $1.52( \pm 0.15)+0.022( \pm 0.015) i$ & $1.33-1.74(\mathrm{RRI})$ & $1.56(\mathrm{RRI})$ \\
& & $0.004-0.046($ IRI) & 0.019 (IRI) \\
\hline
\end{tabular}

Table 4. The code used in Fig. 7 and the respective reference.

\begin{tabular}{ll}
\hline Code & Reference \\
\hline A05 & Ansmann et al. (2005) \\
A09a & Ansmann et al. (2009) \\
A09b & Amiridis et al. (2009) \\
A11 & Alados Arboledas et al. (2011) \\
B03 & Balis et al. (2003) \\
B12a & Baars et al. (2012) \\
B12b & Burton et al. (2012) \\
B13 & Burton et al. (2013) \\
G10 & Giannakaki et al. (2010) \\
G11 & Groß et al. (2011) \\
G13 & Groß et al. (2013) \\
G16 & This study \\
H15 & Heese et al. (2015) \\
I15 & Illingworth et al. (2015) \\
K14 & Kanitz et al. (2014) \\
K12 & Komppula et al. (2012) \\
M05 & Müller et al. (2005) \\
M07 & Müller et al. (2007) \\
M04 & Murayama et al. (2004) \\
N13 & Nicolae et al. (2013) \\
P12 & Preißler et al. (2012) \\
P13 & Preißler et al. (2013) \\
R98 & Reid and Hobbs (1998) \\
T11 & Tesche et al. (2011) \\
W02 & Wandinger et al. (2002) \\
W11 & Weinzierl et al. (2011) \\
\hline
\end{tabular}

and $670 \mathrm{~nm}$, respectively, from AERONET data collected at Skukuza in South Africa. Our results indicate that elevated anthropogenic aerosol layers from urban and industrial activities are characterized by stronger light absorption.

Complex refractive indexes are also reported in Table 3. Real parts of the complex refractive index of these particles are mostly $>1.5$, while imaginary parts vary from 0.007 to $0.04 i$. Lower real parts of the refractive index are found for biomass burning aerosols compared to the urban/industrial particulates, with values ranging from 1.35 to 1.57 . The imaginary parts of the refractive index of biomass burning aerosol layers are $<0.03 i$ (with the exception of one case that shows an imaginary refractive index of $0.046 i$ ). A large variation of refractive indices for the real and imaginary parts is observed for mixed aerosols. This might allude to the different levels of contribution of Kalahari desert dust to biomass burning aerosol layers.

\section{Summary and conclusions}

Thirty-eight aerosol layers of urban/industrial, biomass burning, and mixed aerosols were studied with regard to their optical and microphysical properties at Elandsfontein, South Africa. The combination of Raman lidar observations with backward trajectory analysis, satellite fire observations and in situ data allowed for source identification of the elevated aerosol layers. Measurements of the lidar ratios and depolarization ratios are presented in order to assist in the separation of anthropogenic, biomass burning, and mixtures of aerosols.

A wide range of optical (lidar ratio and depolarization ratio) and microphysical (single-scattering albedo, complex re- 
fractive index) properties was determined for biomass burning aerosols, indicating differences in chemical composition. Aerosols from urban and industrial activities are on average characterized by larger Ångström exponents than (pure or mixed) biomass burning aerosols. Lidar ratios for biomass burning aerosols are among the highest found in the literature, with a mean value of $92 \pm 10 \mathrm{sr}$, while the anthropogenic aerosols are characterized by lower lidar ratios in the range between 41 and $59 \mathrm{sr}$ at $355 \mathrm{~nm}$. Angström exponents were found to be similar for all types of aerosol types under study, with slightly larger values determined for anthropogenic aerosols. Mean effective radii of $0.17 \pm 0.04$ and $0.1 \pm 0.03 \mu \mathrm{m}$ were calculated for biomass burning and urban/industrial aerosols, respectively. We have also shown that, in certain instances, biomass burning aerosols may contain a small number of desert dust particles, resulting in higher depolarization ratios and lower lidar ratios than the values reported for pure biomass burning aerosols. Moderately absorbing particles were found for biomass burning layers with a mean single-scattering albedo of $0.9 \pm 0.06$. Mixed aerosols were found more absorbing with a mean singlescattering albedo of $0.88 \pm 0.07$. A slightly lower mean single-scattering albedo of $0.87 \pm 0.06$ was found for urban/industrial aerosol layers. However, this value was larger than the values reported for the same site from ground-based in situ measurements. Our optical and microphysical results for the analysed aerosol types agreed very well with similar studies reported in the literature.

Ground-based lidar networks provide information on the vertical and horizontal distribution of optical aerosol properties in a systematic and statistically significant manner. Different lidar networks that are globally distributed observe aerosols in Europe, South America, Asia and North America. The analysis of lidar measurements presented here could assist in bridging existing gaps with regard to our knowledge of the vertical distribution of optical and microphysical aerosols in the South African atmosphere, since limited long-term data of this nature are available for this region. Our results could also be useful for lidar ratio selection schemes needed for elastic-backscatter lidars. In that sense our findings could be used in advancing lidar algorithms used for present and/or future satellite lidar missions.

\section{Data availability}

The data are available upon request (contact mail: eleni.giannakaki@fmi.fi).

Acknowledgements. This work has been partly supported by the European Commission 6th Framework Programme under the EUCAARI project (contract no. 036833-2). Elina Giannakaki acknowledges the support of the Academy of Finland (project no. 270108). The authors acknowledge the staff of the North-West University for valuable assistance and routine maintenance of the lidar. We also acknowledge Eskom and Sasol for their logistical support for measurements at Elandsfontein.

Edited by: M. Tesche

\section{References}

Alados Arboledas, L., Müller, D., Guerrero Rascado, J. L., Navas Guzmán, F., Pérez Ramírez, D., and Olmo, F. J.:, Optical and microphysical properties of fresh biomass burning aerosol retrieved by Raman lidar, and star and sun-photometry, Geophys. Res. Lett., 38, L01807, doi:10.1029/2010GL045999, 2011.

Althausen, D., Engelmann, R., Baars, H., Heese, B., Ansmann, A., Müller, D., and Komppula, M.: Portable Raman Lidar Polly XT for Automated Profiling of Aerosol Backscatter, Extinction, and Depolarization, J. Atmos. Ocean. Tech., 26, 2366-2378, doi:10.1175/2009jtecha1304.1, 2009.

Amiridis, V., Balis, D. S., Giannakaki, E., Stohl, A., Kazadzis, S., Koukouli, M. E., and Zanis, P.: Optical characteristics of biomass burning aerosols over Southeastern Europe determined from UVRaman lidar measurements, Atmos. Chem. Phys., 9, 2431-2440, doi:10.5194/acp-9-2431-2009, 2009.

Ansmann, A., Wandinger, U., Riebesell, M., Weitkamp, C., and Michaelis, W.: Independent measurement of extinction and backscatter profiles in cirrus clouds by using a combined Raman elastic-backscatter lidar, Appl. Optics, 31, 7113-7131, doi:10.1364/AO.31.007113,1992.

Ansmann, A., Engelmann, R., Althausen, D., Wandinger, U., Hu, M., Zhang, Y., and He, Q.: High aerosol load over the Pearl River Delta, China, observed with Raman lidar and Sun photometer, Geophys. Res. Lett., 32, L13815, doi:10.1029/2005GL023094, 2005.

Ansmann A., Baars, H., Tesche, M., Müller, D., Althausen, D., Engelmann, R., Pauliquevis, T., and Artaxo, P.: Dust and smoke transport from Africa to South America: Lidar profiling over Cape Verde and the Amazon rainforest, Geophys. Res. Lett., 36, L11802, doi:10.1029/2009GL037923, 2009.

Baars, H., Ansmann, A., Althausen, D., Engelmann, R., Heese, B., Müller, D., Artaxo, P., Paixao, M., Pauliquevis, T., and Souza, R.: Aerosol profiling with lidar in Amazon Basin during the wet and dry season, J. Geophys. Res., 117, D21201, doi:10.1029/2012JD018338, 2012.

Baars, H., Kanitz, T., Engelmann, R., Althausen, D., Heese, B., Komppula, M., Preißler, J., Tesche, M., Ansmann, A., Wandinger, U., Lim, J.-H., Ahn, J. Y., Stachlewska, I. S., Amiridis, V., Marinou, E., Seifert, P., Hofer, J., Skupin, A., Schneider, F., Bohlmann, S., Foth, A., Bley, S., Pfüller, A., Giannakaki, E., Lihavainen, H., Viisanen, Y., Hooda, R. K., Pereira, S. N., Bortoli, D., Wagner, F., Mattis, I., Janicka, L., Markowicz, K. M., Achtert, P., Artaxo, P., Pauliquevis, T., Souza, R. A. F., Sharma, V. P., van Zyl, P. G., Beukes, J. P., Sun, J., Rohwer, E. G., Deng, R., Mamouri, R.-E., and Zamorano, F.: An overview of the first decade of Polly ${ }^{\text {NET }}$ : an emerging network of automated Raman-polarization lidars for continuous aerosol profiling, Atmos. Chem. Phys., 16, 5111-5137, doi:10.5194/acp-165111-2016, 2016.

Balis, D. S., Amiridis, V., Zerefos, C., Gerasopoulos, E., Andreae, M., Zanis, P., Kazantzidis, A., Kazadzis, S., and Pa- 
payannis A.: Raman lidar and Sun photometric measurements of aerosol optical properties over Thessaloniki, Greece during a biomass burning episode 2003, Atmos. Environ., 37, 4529-4538, doi:10.1016/S1352-2310(03)00581-8, 2003.

Behrendt, A. and Nakamura, T.: Calculation of the calibration constant of polarization lidar and its dependency on atmospheric temperature, Opt. Express, 10, 805-817, 2002.

Burton, S. P., Ferrare, R. A., Hostetler, C. A., Hair, J. W., Rogers, R. R., Obland, M. D., Butler, C. F., Cook, A. L., Harper, D. B., and Froyd, K. D.: Aerosol classification using airborne High Spectral Resolution Lidar measurements - methodology and examples, Atmos. Meas. Tech., 5, 73-98, doi:10.5194/amt-5-73-2012, 2012.

Burton, S. P., Ferrare, R. A., Vaughan, M. A., Omar, A. H., Rogers, R. R., Hostetler, C. A., and Hair, J. W.: Aerosol classification from airborne HSRL and comparisons with the CALIPSO vertical feature mask, Atmos. Meas. Tech., 6, 13971412, doi:10.5194/amt-6-1397-2013, 2013.

Cairo, F., Di Donfrancesco, G., Adriani, A., Pulvirenti, L., and Fierli, F.: Comparison of various linear depolarization parameters measured by lidar, Appl. Optics, 38, 4425-4432, doi:10.1364/AO.38.004425,1999.

Campbell, J. R., Welton, E. J., Spinhirne, J. D., Ji, Q., Tsay, S. C., Piketh, S. J., Barenbrug, M., and Holben, B. N.: Micropulse lidar observations of tropospheric aerosols over northeastern South Africa during the ARREX and SAFARI 2000 dry season experiments, J. Geophys. Res., 108, 8497, doi:10.1029/2002jd002563, 2003.

Draxler, R. R. and Hess, G. D.: Description of the HYSPLIT 4 modeling system, NOAA Tech Memo, ERL ARL-224, 24, NOAA, Silver Spring, Md., USA, 1997.

Eck, T. F., Holben, B. N., Ward, D. E., Mukelabai, M. M., Dubovik, O., Smirnov, A., Schafer, J. S., Hsu, N. C., Piketh, S. J., Queface, A., Le Roux, J., Swap, R. J., and Slutsker, I.: Variability of biomass burning aerosol optical characteristics in southern Africa during the SAFARI 2000 dry season campaign and a comparison of single scattering albedo estimates from radiometric measurements, J. Geophys. Res., 108, 8477, doi:10.1029/2002jd002321, 2003.

Edwards, D. P., Emmons, L. K., Gille, J. C., Chu, A., Attie, J. L., Giglio, L., Wood, S. W., Haywood, J., Deeter, M. N., Massie, S. T., Ziskin, D. C., and Drummond, J. R.: Satellite-onserved pollution from Southern Hemisphere biomass burning, J. Geophys. Res., 111, D14312, doi:10.1029/2005JD006655, 2006.

Engelmann, R., Kanitz, T., Baars, H., Heese, B., Althausen, D., Skupin, A., Wandinger, U., Komppula, M., Stachlewska, I. S., Amiridis, V., Marinou, E., Mattis, I., Linné, H., and Ansmann, A.: The automated multiwavelength Raman polarization and water-vapor lidar Polly ${ }^{X T}$ : the neXT generation, Atmos. Meas. Tech., 9, 1767-1784, doi:10.5194/amt-9-1767-2016, 2016.

Formenti, P., Winkler, H., Fourie, P., Piketh, S., Makgopa, B., Helas, G., and Andreae, M. O.: Aerosol optical depth over a remote semi-arid region of South Africa from spectral measurements of the daytime solar extinction and the nighttime stellar extinction, Atmos. Res., 62, 11-32, doi:10.1016/s0169-8095(02)00021-2, 2002.

Formenti, P., Elbert, W., Maenhaut, W., Haywood, J., Osborne, S., and Andreae, M. O.: Inorganic and carbonaceous aerosols during the Southern African Regional Science Initiative (SAFARI 2000) experiment: Chemical characteristics, physical properties, and emission data for smoke from African biomass burning, J. Geophys. Res., 108, 8488, doi:10.1029/2002jd002408, 2003.

Forster, P., Ramaswamy, V., Artaxo, P., Berntsen, T., Betts, R., Fahey, D., Haywood, J., Lean, J., Lowe, D., Myhre, G., Nganga, J., Prinn, R., Raga, G., Schulz, M., and Dorland, R. V.: Changes in atmospheric constituents and in radiative forcing. Climate Change 2007: The Physical Science Basis. Contribution of Working Group I to the Fourth Assessment Report of the Intergovernmental Panel on Climate Change, Cambridge Univ. Press, Cambridge, UK and New York, NY, USA, 129-234, 2007.

Fernlad, G. F.: Analysis of atmospheric lidar observations: some comments, Appl. Optics, 23, 652-653, 1984.

Freiman, M. T. and Piketh, S. J.: Air transport into and out of the industrial Highveld region of South Africa, J. Appl. Meteorol., 42, 994-1002, doi:10.1175/15200450(2003)042<0994:ATIAOO>2.0.CO;2, 2003.

Freudenthaler, V., Esselborn, M., Wiegner, M., Heese, B., Tesche, M., Ansmann, A., Müller, D., Althausen, D., Wirth, M., Fix, A., Ehret, G., Knippertz, P., Toledano, C., Gasteiger, J., Garhammer, M., and Seefeldner, M.: Depolarization ratio profiling at several wavelengths in pure Saharan dust during SAMUM 2006, Tellus B, 61, 165-179, doi:10.1111/j.1600-0889.2008.00396.x, 2009.

Giannakaki, E., Balis, D. S., Amiridis, V., and Zerefos, C.: Optical properties of different aerosol types: seven years of combined Raman-elastic backscatter lidar measurements in Thessaloniki, Greece, Atmos. Meas. Tech., 3, 569-578, doi:10.5194/amt-3569-2010, 2010.

Giannakaki, E., Pfüller, A., Korhonen, K., Mielonen, T., Laakso, L., Vakkari, V., Baars, H., Engelmann, R., Beukes, J. P., Van Zyl, P. G., Josipovic, M., Tiitta, P., Chiloane, K., Piketh, S., Lihavainen, H., Lehtinen, K. E. J., and Komppula, M.: One year of Raman lidar observations of free-tropospheric aerosol layers over South Africa, Atmos. Chem. Phys., 15, 5429-5442, doi:10.5194/acp15-5429-2015, 2015.

Giglio, L., Randerson, J. T., van der Werf, G. R., Kasibhatla, P. S., Collatz, G. J., Morton, D. C., and DeFries, R. S.: Assessing variability and long-term trends in burned area by merging multiple satellite fire products, Biogeosciences, 7, 1171-1186, doi:10.5194/bg-7-1171-2010, 2010.

Groß, S, Tesche, M., Freudenthaler, V., Toledano, C., Wiegner, M., Ansmann, A., Althausen, D., and Seefeldner, M.: Characterization of Saharan dust, marine aerosols and mixtures of biomassburning aerosols and dust by means of multi-wavelength depolarization and Raman lidar measurements during SAMUM 2, Tellus B, 63, 706-724, doi:10.1111/j.1600-0889.2011.00556.x, 2011.

Groß, S., Esselborn, M., Weinzierl, B., Wirth, M., Fix, A., and Petzold, A.: Aerosol classification by airborne high spectral resolution lidar observations, Atmos. Chem. Phys., 13, 2487-2505, doi:10.5194/acp-13-2487-2013, 2013.

Hänel, A., Baars, H., Althausen, D., Ansmann, A., Engelmann, R., and Sun, Y. J.: One-year aerosol profiling with EUCAARI Raman lidar at Shangdianzi GAW station: Beijing plume and seasonal variation, J. Geophys. Res., 117, D13201, doi:10.1029/2012JD017577, 2012.

Heese, B., Althausen, D., Baars, H., Bohlmann, S., and Deng, R.: Aerosol properties over Southeastern China from multiwavelength Raman and depolarization lidar measurents, in: Reviewed 
and Revised Papers of 27th ILRC International Laser Radar Conference, 5-10 July 2015, New York, USA, 2015.

Ichoku, C., Remer, L. A., Kaufman, Y. J., Levy, R., Chu, D. A., Tanre, D., and Holben, B. N.: MODIS observation of aerosols and estimation of aerosol radiative forcing over southern Africa during SAFARI 2000, J. Geophys. Res., 108, 8499, doi:10.1029/2002jd002366, 2003.

Illingworth, A. J., Barker, H. W., Beljaars, A., Ceccaldi, M., Chepfer, H., Cole, J., Delanoë, J., Domenech, C., Donovan, D. P., Fukuda, S., Hirakata, M., Hogan, R. J., Huenerbein, A., Kollias, P., Kubota, T., Nakajima, T., Nakajima, T. Y., Nishizawa, T., Ohno, Y., Okamoto, H., Oki, R., Sato, K., Satoh, M., Shephard, M., Wandinger, U., Wehr, T., and Van Zadelhoff, G.-J.: The EarthCARE Satellite: The next step forward in global measurements of clouds, aerosols, precipitation and radiation, B. Am. Meteorol. Soc., 96, 1311-1311, doi:10.1175/BAMS-D-1200227.1, 2015.

IPCC: The Physical Science Basis, Contribution of Working Group I to the Fifth Assessment Report of the Intergovernmental Panel on Climate Change, edited by: Stocker, T. F., Qin, D., Plattner, G.-K, Tignor, M., Allen, S. K., Boschung, J., Nauels, A., Xia, Y., Bex, V., and Midgley, P. M., Cambridge University Press, Cambridge, UK and New York, NY, USA, 2013.

Kanitz, T., Engelmann, R., Heinold, B., Baars, H., Skupin, A., and Ansmann A.: Tracking the Saharan Air Layer with shipborne lidar across the tropical Atlantic, Geophys. Res. Lett., 41, 10441050, doi:10.1002/2013GL058780, 2014.

Klett, J. D.: Stable analytical inversion solution for processing lidar returns, Appl. Optics, 20, 211-220, doi:10.1364/AO.20.000211, 1981.

Komppula, M., Mielonen, T., Arola, A., Korhonen, K., Lihavainen, H., Hyvärinen, A.-P., Baars, H., Engelmann, R., Althausen, D., Ansmann, A., Müller, D., Panwar, T. S., Hooda, R. K., Sharma, V. P., Kerminen, V.-M., Lehtinen, K. E. J., and Viisanen, Y.: Technical Note: One year of Raman-lidar measurements in Gual Pahari EUCAARI site close to New Delhi in India - Seasonal characteristics of the aerosol vertical structure, Atmos. Chem. Phys., 12, 4513-4524, doi:10.5194/acp-12-4513-2012, 2012.

Kulmala, M., Asmi, A., Lappalainen, H. K., et al.: General overview: European Integrated project on Aerosol Cloud Climate and Air Quality interactions (EUCAARI) - integrating aerosol research from nano to global scales, Atmos. Chem. Phys., 11, 13061-13143, doi:10.5194/acp-11-13061-2011, 2011.

Laakso, L., Vakkari, V., Virkkula, A., Laakso, H., Backman, J., Kulmala, M., Beukes, J. P., van Zyl, P. G., Tiitta, P., Josipovic, M., Pienaar, J. J., Chiloane, K., Gilardoni, S., Vignati, E., Wiedensohler, A., Tuch, T., Birmili, W., Piketh, S., Collett, K., Fourie, G. D., Komppula, M., Lihavainen, H., de Leeuw, G., and Kerminen, V.-M.: South African EUCAARI measurements: seasonal variation of trace gases and aerosol optical properties, Atmos. Chem. Phys., 12, 1847-1864, doi:10.5194/acp-12-1847-2012, 2012.

Lourens, A. S. M., Butler, T. M., Beukes, J. P., van Zyl, P. G., Beirle, S., Wagner, T. K., Heue, K. P., Pienaar, J. J., Fourie, G. D., and Lawrence, M. G.: Re-evaluating the $\mathrm{NO}_{2}$ hotspot over the South African Highveld, S. Afr. J. Sci., 108, 54-59, doi:10.4102/sajs.v108i11/12.1146, 2012.

Mamouri, R. E. and Ansmann, A.: Fine and coarse dust separation with polarization lidar, Atmos. Meas. Tech., 7, 3717-3735, doi:10.5194/amt-7-3717-2014, 2014.
Mamouri, R. E., Ansmann, A., Nisantzi, A., Kokkalis, P., Schwarz, A. and Hadjimitsis D.: Low Arabian dust extinctionto-backscatter ratio, Geophys. Res. Lett., 40, 4762-4766, doi:10.1002/grl.50898, 2013.

Mishchenko, M., Travis, L. D., Kahn, R. A. and West, R. A.: Modeling phase functions for dustlike tropospheric aerosols using a shape mixture of randomly oriented polydisperse spheroids, J. Geophys. Res., 102, 16831-16847, 1997.

Müller, D., Wandinger, U., and Ansmann, A.: Microphysical particle parameters from extinction and backscatter lidar data by inversion with regularization: theory, Appl. Optics 38, 2346-2357, 1999a.

Müller, D., Wandinger, U., and Ansmann, A.: Microphysical particle parameters from extinction and backscatter lidar data by inversion with regularization: simulation, Appl. Optics 38, 23582368, 1999b.

Müller, D., Wandinger, U., Althausen, D., and Fiebig, M.: Comprehensive particle characterization from three-wavelength Raman-lidar observations, Appl. Optics, 40, 4863-4869, doi:10.1364/AO.40.004863, 2001.

Müller, D., Mattis, I., Wandinger, U., Ansmann, A., Althausen, D., Dubovik, O., Eckhardt, S., and Stohl, A.: Saharan dust over a central European EARLINET-AERONET site: combined observations with Raman lidar and Sun photometer, J. Geophys. Res., 108, 4345, doi:10.1029/2002JD002918, 2003.

Müller, D., Mattis, I., Wandinger, U., Ansmann, A., Althausen, D., and Stohl, A.: Raman lidar observations of aged Siberian and Canadian forest fire smoke in the free troposphere over Germany in 2003: Microphysical particle characterization, J. Geophys. Res., 110, D17201, doi:10.1029/2004JD005756, 2005.

Müller, D., Ansmann, A., Mattis, I., Tesche, M., Wandinger, U., Althausen, D., and Pissani, G.: Aerosol-type dependent lidar raios observed with Raman lidar, J. Geophys. Res., 12, D16202, doi:10.1029/2006JD008292, 2007.

Murayama, T., Okamoto, H., Kaneyasu, N., Kamataki, H., and Miura, K.: Application of lidar depolarization measurement in the atmospheric boundary layer: Effects of dust and sea-salt particles, J. Geophys. Res., 104, 31781-31792, doi:10.1029/1999JD900503, 1999.

Murayama, T., Müller, D., Wada, K., Shimizu, A., Sekigushi, M., and Tsukamato, T.: Characterization of Asian dust and Siberian smoke with multi-wavelength Raman lidar over Tokyo, Japan in spring 2003, Geophys. Res. Lett., 31, L23103, doi:10.1029/2004GL021105, 2004.

Nicolae, D., Nemuc, A., Müller, D., Talianu, C., Vasilescu, J., Belegante L., and Kolgotin, A.: Characterization of fresh and aged biomass burning events using multiwavelength Raman lidar and mass spectrometry, J. Geophys. Res., 118, 2956-2965, doi:10.1002/jgrd.50324, 2013.

Nisantzi, A., Mamouri, R. E., Ansmann, A., and Hadjimitsis, D.: Injection of mineral dust into the free troposphere during fire events observed with polarization lidar at Limassol, Cyprus, Atmos. Chem. Phys., 14, 12155-12165, doi:10.5194/acp-14 12155-2014, 2014.

Noh, Y. M., Müller, D., Shin, D. H., Lee, H. L., Jung, J. S., Lee, K. H., Cribb, M., Li, Z., and Kim Y. J.: Optical and microphysical properties of severe haze and smoke aerosol measured by integrated remote sensing techniques in Gwangju, Korea, Atmos. 
Environ., 43, 879-888, doi:10.1016/j.atmosenv.2008.10.058, 2009.

Omar, A., Winker, D., Vaughan, M., Hu, Y., Trepte, C., Ferrare, R., Lee, K., Hostetler, C., Kittaka, C., Rogers, R., Kuehn, R., and Liu, Z.: The CALIPSO Automated Aerosol Classification and Lidar Ratio Selection Algorithm, J. Atmos. Ocean. Tech., 26, 1994-2014, doi:10.1175/2009JTECHA1231.1, 2009.

Piketh, S. J., Tyson, P. D., and Steffen, W.: Aeolian transport from southern Africa and iron fertilization of marine biota in the South Indian Ocean, S. Afr. J. Sci., 96, 244-246, 2000.

Piketh, S. J., Swap, R. J., Maenhaut, W., Annegarn, H. J., and Formenti, P.: Chemical evidence of long-range atmospheric transport over southern Africa, J. Geophys. Res., 107, 4817, doi:10.1029/2002jd002056, 2002.

Pósfai, M., Simonics, R., Li, J., Hobbs, P. V., and Buseck, P. R.: Individual aerosol particles from biomass burning in southern Africa: 1. Compositions and size distributions of carbonaceous particles, J. Geophys. Res., 108, 2156-2202, doi:10.1029/2002JD002291, 2003.

Preißler, J., Bravo-Aranda, J., Wagner, F., Granados-Muñoz, M. J., Navas-Guzmán, F., Guerrero-Rascado, J. L., Lyamani, H., and Alados-Arboledas, L.: Optical properties of free tropospheric aerosol from multi-wavelength Raman lidars over the southern Iberian Peninsula, in: Proceedings of the 9th International Symposium on Tropospheric Profinling, 3-7 September 2012, l'Aquila, Italy, ISBN 978-90-815839-4-7, 2012.

Preißler, J., Wagner, F., Guerrero-Rascado, J. L., and Silva, A. M.: Two years of free-tropospheric aerosol layers observed over Portugal by lidar, J. Geophys. Res., 118, 3676-3686, doi:10.1002/jgrd.50350, 2013.

Queface, A. J., Piketh, S. J., Eck, T. F., Tsay, S. C., and Mavume, A. F.: Climatology of aerosol optical properties in Southern Africa, Atmos. Environ., 45, 2910-2921, doi:10.1016/j.atmosenv.2011.01.056, 2011.

Radke, L. F., Heggs, D. A., Lyons, H., Brook, C. A., Hobbs, P. V., Weiss, R., and Rasmussen, R.: Airborne measurements on smoke from biomass burning, in: Aerosols and Climate, edited by: Hobbs, P. V. and McCormick, M. P., Deepak, A., Hampton, VA, USA, 411-422, 1998.

Reid, J. S. and Hobbs, P. V.: Physical and optical properties of smoke from individual biomass fires in Brazil, J. Geophys. Res., 103, 32013-32031, doi:10.1029/98JD00159, 1998.

Ross, K. E., Piketh, S. J., Bruintjes, R. T., Burger, R. P., Swap, R. J., and Annegarn, H. J.: Spatial and seasonal variations in CCN distribution and the aerosol-CCN relationship over southern Africa, J. Geophys. Res., 108, 8481, doi:10.1029/2002JD002384, 2003.

Roy, D. P., Frost, P. G. H., Justice, C. O., Landmann, T., Le Roux, J. L., Gumbo, K., Makungwa, S., Dunham, K., du Toit, R., Mhwandagara, K., Zacarias, A., Tacheba, B., Dube, O. P., Pereira, J. M. C., Mushove, P., Morisette, J. T., Santhana-Vannan S. K., and Davies, D.: The Southern Africa Fire Network (SAFnet) reigional burned-area product-validation protocol, Int. J. Remote Sens., 26, 4265-4292, 2005.

Schneider, P., Lahoz, W. A., and van der A, R.: Recent satellitebased trends of tropospheric nitrogen dioxide over large urban agglomerations worldwide, Atmos. Chem. Phys., 15, 12051220, doi:10.5194/acp-15-1205-2015, 2015.

Shimizu, A., Sugimoto, N., Matsui, I., Arao, K., Uno, I., Murayama, T., Kagawa, N., Aoki, K., Uchiyama, A., and Yamazaki, A.: Con- tinuous observations of Asian dust and other aerosols by polarization lidars in China and Japan during ACE-Asia, J. Geophys. Res., 109, D19S17, doi:10.1029/2002JD003253, 2004.

Shin, S.-K., Müller, D., Lee, C., Lee, K. H., Shin, D., Kim, Y. J., and Noh, Y. M.: Vertical variation of optical properties of mixed Asian dust/pollution plumes according to pathway of air mass transport over East Asia, Atmos. Chem. Phys., 15, 6707-6720, doi:10.5194/acp-15-6707-2015, 2015.

Sugimoto, N., Uno, I., Nishikawa, M., Shimizu, A., Matsui, I., Dong, X., Chen, Y., and Quan, H.: Record heavy Asian dust in Beijing in 2002: Observations and model analysis of recent events, Geophys. Res. Lett., 30, 1640, doi:10.1029/2002GL016349, 2003.

Tesche, M., Ansmann, A., Müller, D., Althausen, D., Engelmann, R., Freudenthaler, V., and Groß, S.: Vertically resolved separation of dust and smoke over Cape Verde using multiwavelength Raman and polarization lidars during Saharan Mineral Dust Experiment 2008, J. Geophys. Res., 114, D13202, doi:10.1029/2009JD011862, 2009.

Tesche, M., Gross, S., Ansmann, A., Müller, D., Althausen, D., Freudenthaler, V., and Esselborn, M.: Profiling of Saharan dust and biomass-burning smoke with multiwavelength polarization Raman lidar at Cape Verde, Tellus B, 63, 649-676, doi:10.1111/j.1600-0889.2011.00548.x, 2011.

Tesfaye, M., Sivakumar, V., Botai, J., and Tsidu, G. M.: Aerosol climatology over South Africa based on 10 years of Multiangle Imaging Spectroradiometer (MISR) data, J. Geophys. Res., 116, D20216, doi:10.1029/2011jd016023, 2011.

Tiitta, P., Vakkari, V., Croteau, P., Beukes, J. P., van Zyl, P. G., Josipovic, M., Venter, A. D., Jaars, K., Pienaar, J. J., Ng, N. L., Canagaratna, M. R., Jayne, J. T., Kerminen, V.-M., Kokkola, H., Kulmala, M., Laaksonen, A., Worsnop, D. R., and Laakso, L.: Chemical composition, main sources and temporal variability of $\mathrm{PM}_{1}$ aerosols in southern African grassland, Atmos. Chem Phys., 14, 1909-1927, doi:10.5194/acp-14-1909-2014, 2014.

Twomey, S.: Introduction to the Mathematics of Inversion in Remotes Sensing and Indirect Measurements, Elsevier Scientific, New York, USA, 1977.

Venter, A. D., Vakkari, V., Beukes, J. P., van Zyl, P. G., Laakso, H., Mabaso, D., Tiitta, P., Josipovic, M., Kulmala, M., Pienaar, J. J., and Laakso, L.: An air quality assessment in the industrialised western Bushveld Ignous Complex, South Africa, S. Afr. J. Sci., 108, 1059, doi:10.4102/sajs.v108i9/10.1059, 2012.

Veselovskii, I., Kolgotin, A., Griaznov, V., Müller, D., Wandinger, U., and Whiteman, D. N.: Inversion with regularization for the retrieval of tropospheric aerosol parameters from multiwavelength lidar sounding, Appl. Optics, 41, 3685-3699, 2002.

Veselovskii, I., Kolgotin, A., Griaznov, V., Müller, D., Franke, K., and Whiteman, D. N.: Inversion of multiwavelength Raman lidar data for retrieval of bimodal aerosol size distribution, Appl. Optics, 43, 1180-1195, 2004.

Wagner, F. and Silva, A. M.: Some considerations about Ångström exponent distributions, Atmos. Chem. Phys., 8, 481-489, doi:10.5194/acp-8-481-2008, 2008.

Wandinger, U. and Ansmann, A.: Experimental determination of the lidar overlap profile with Raman lidar, Appl. Optics, 41, 511514, doi:10.1364/AO.41.000511, 2002.

Wandinger, U., Müller, D., Böckmann, C., Althausen, D., Matthias, V., Bösenberg, J., Weiß, V., Fiebig, M., Wendisch, M., Stohl, 
A., and Ansmann A.: Optical and microphysical characterization of biomassburning and industrial-pollution aerosols from multiwavelength lidar and aircraft measurements, J. Geophys. Res., 107, 8125, doi:10.1029/2000JD000202, 2002.

Weinzierl, B., Sauer, D., Esselborn, M., Petzold, A., Veira, A., Rose, M., Mund, S., Wirth, M., Ansmann, A., Tesche, M., Gross, S., and Freudenthaler, V.: Microphysical and optical properties of dust and tropical biomass burning aerosol layers in the Cape Verde region - an overview of the airborne in situ and lidar measurements during SAMUM-2, Tellus, 63B, 589-618, doi:10.1111/j.1600-0889.2011.00566.x, 2011.
Wenig, M., Spichtinger, N., Stohl, A., Held, G., Beirle, S., Wagner, T., Jähne, B., and Platt, U.: Intercontinental transport of nitrogen oxide pollution plumes, Atmos. Chem. Phys., 3, 387-393, doi:10.5194/acp-3-387-2003, 2003.

Winkler, H., Formenti, P., Esterhuyse, D. J., Swap, R. J., Helas, G., Annegarn, H. J., and Andreae, M. O.: Evidence for largescale transport of biomass burning aerosols from sunphotometry at a remote South African site: Atmos. Environ., 42, 5569-5578, doi:10.1016/j.atmosenv.2008.03.031, 2008. 